\title{
On the formaldehyde content of the silages prepared with formaldehyde-containing preservative
}

\author{
Aino Rauramaa and Matti Kreula \\ Biochemical Research Institute \\ Kalevankatu 56 b, 00180 Helsinki 18, Finland
}

\begin{abstract}
The free formaldehyde contents of 180 samples of silages preserved with ,Viherliuos were measured during the indoor-feeding period 1975-76. The mean formaldehyde content of the silages was 120 (range $20-500$ ) and 59 (range 10-1250) $\mathrm{mg} / \mathrm{kg}$ fresh weight respectively in autumn 1975 and spring 1976.
\end{abstract}

When formaldehyde-containing preservatives are used in the making of silage the content of free formaldehyde may be as high as $1000-2000 \mathrm{mg} / \mathrm{kg}$ at the beginning of ensiling. In general, free formaldehyde disappears from silage during ensiling, but may be present in ripe silage (KIURU et al. 1975, BECK and Gross 1974, HoNIG and RoHr 1973). If free formaldehyde-containing silage is consumed by cows, part of the free formaldehyde may be transferred to milk (BECK and Gross 1974, Kreula and RauramaA 1976).

The aim of this study was to measure the free formaldehyde content of the silages preserved with "Viherliuos» prepared in different areas of Finland. In 1975 the Viherliuos contained $55 \%$ formalin, $30 \%$ acetic acid solution and $15 \%$ stabiliser solution. This investigation is part of the Randomsample survey in the Valio laboratory in 1975-76.

\section{Experimental}

\section{Samples}

The silage samples were taken at random from those preserved with Viherliuos and sent to the 1975-76 Random-sample Survey. The Viherliuos dose was 1-10 litres per ton of grass as reported from the Survey.

\section{Determination of formaldehyde}

The formaldehyde contents of the samples were measured by a slightly modified BECK and Gross (1974) method. The chromotropic acid reaction 
was carried out according to the AOAC instructions (1975). Silage samples $(50 \mathrm{~g})$ were first homogenised with twice-distilled water $(450 \mathrm{~g})$ in a Waring Commercial Blendor.

The following determinations were made on silage "press juicen, obtained in the laboratory by submitting the sample to pressure: $\mathrm{pH}$ and ammonium nitrogen were determined by means of ion-specific electrodes, lactate by paper chromatography (FIRMIN and GRAY 1974 and sugar content by the Clinitest method (HEIKONEN et al. 1976).

\section{Results and discussion}

The mean formaldehyde content in the 45 autumn samples was $120 \mathrm{mg} / \mathrm{kg}$ fresh weight (range $20-500 \mathrm{mg} / \mathrm{kg}$ ) and in the 141 spring samples $59 \mathrm{mg} / \mathrm{kg}$ (range $10-1250 \mathrm{mg} / \mathrm{kg}$ ). The highest formaldehyde content in both autumn and spring was in silages of $\mathrm{pH} \geq 4.2$ (Table 1 ).

When the formaldehyde contents of the silages were compared with their sugar, ammonia and lactate contents, it was seen that the amounts of free formaldehyde rose when the sugar content increased (Table 2), but decreased when the ammonia content (Table 3) and lactate content (Table 4) increased.

The free formaldehyde content of the ripe silages did not correlate with the amount of Viherliuos added to the silages.

Table 1. Relationship between free formaldehyde content and $\mathrm{pH}$ in silages preserved with Viherliuos in 1975.

\begin{tabular}{|c|c|c|c|c|c|c|}
\hline \multirow{3}{*}{$\mathrm{pH}$ range } & \multicolumn{6}{|c|}{ Formaldehyde $\mathrm{mg} / \mathrm{kg}$ fresh weight } \\
\hline & \multicolumn{3}{|c|}{ Autumn 1975} & \multicolumn{3}{|c|}{ Spring 1976} \\
\hline & $\overline{\mathbf{x}}$ & $\mathbf{s}$ & $\mathrm{n}$ & $\overline{\mathbf{x}}$ & $\mathbf{s}$ & $\mathrm{n}$ \\
\hline 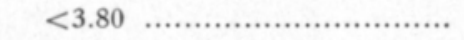 & 20.0 & 0 & 1 & 24.5 & 12.6 & 44 \\
\hline 3.8-3.99 „.......................... & 51.0 & 23.3 & 5 & 49.3 & 96.7 & 44 \\
\hline $4.0-4.19$............................. & 59.3 & 37.2 & 3 & 49.8 & 48.1 & 26 \\
\hline 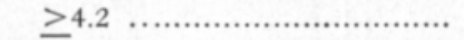 & 137.2 & 122.7 & 36 & 139.3 & 246.1 & 27 \\
\hline 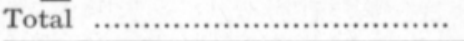 & 119.8 & 115.5 & 45 & 59.9 & 127.4 & 141 \\
\hline
\end{tabular}

Table 2. Relation between free formaldehyde and sugar contents in silages prepared with Viherliuos in 1975

\begin{tabular}{|c|c|c|c|c|c|c|}
\hline \multirow[t]{2}{*}{ Sugar, $\%$} & \multicolumn{6}{|c|}{ Formaldehyde $\mathrm{mg} / \mathrm{kg}$ fresh weight } \\
\hline & $\overline{\mathbf{x}}$ & $\mathbf{s}$ & $\mathrm{n}$ & $\overline{\mathbf{x}}$ & $\mathbf{s}$ & n \\
\hline$<0.5 \ldots \ldots \ldots \ldots$ & 57.5 & 46.6 & 4 & 27.8 & 14.6 & 38 \\
\hline 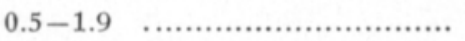 & 67.1 & 38.0 & 16 & 27.1 & 15.0 & 51 \\
\hline 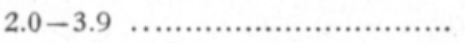 & 112.0 & 69.8 & 10 & 68.8 & 124.1 & 30 \\
\hline 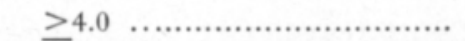 & 198.0 & 161.0 & 15 & 173.0 & 261.0 & 22 \\
\hline
\end{tabular}


Table 3. Relation between free formaldehyde and ammonia contents in silages with Viherliuos in 1975 .

\begin{tabular}{|c|c|c|c|c|c|c|c|}
\hline \multirow{3}{*}{\multicolumn{2}{|c|}{$\mathrm{NH}_{3}, \mathrm{~g} / \mathrm{l}$}} & \multicolumn{6}{|c|}{ Formaldehyde $\mathrm{mg} / \mathrm{kg}$ fresh weight } \\
\hline & & \multicolumn{3}{|c|}{ Autumn 1975} & \multicolumn{3}{|c|}{ Spring 1976} \\
\hline & & $\overline{\mathbf{x}}$ & s & $\mathrm{n}$ & $\overline{\mathbf{x}}$ & s & $\mathrm{n}$ \\
\hline$<0.25$ & .... & 166.5 & 137.6 & 17 & 263.9 & 399.8 & 39 \\
\hline $0.25-0.49$ & .... & 86.5 & 47.8 & 12 & 53.0 & 50.9 & 55 \\
\hline $0.50-0.74$ & ........................... & 80.0 & 46.4 & 8 & 42.6 & 86.8 & 59 \\
\hline$\geq 0.75$ & 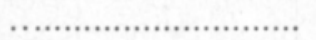 & 55.0 & 34.4 & 7 & 27.8 & 17.4 & 18 \\
\hline
\end{tabular}

Table 4. Relation between free formaldehyde and lactate contents in silages prepared with Viherliuos in 1975

\begin{tabular}{|c|c|c|c|c|c|c|}
\hline \multirow{3}{*}{ Lactate, \% } & \multicolumn{6}{|c|}{ Formaldehyde $\mathrm{mg} / \mathrm{kg}$ fresh weight } \\
\hline & \multicolumn{3}{|c|}{ Autumn 1975} & \multicolumn{3}{|c|}{ Spring 1976} \\
\hline & $\overline{\mathbf{x}}$ & $\mathbf{s}$ & $\mathrm{n}$ & $\overline{\mathbf{x}}$ & s & $\mathrm{n}$ \\
\hline 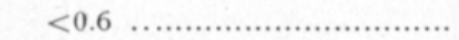 & 195.7 & 162.0 & 14 & 135.0 & 93.3 & 11 \\
\hline $0.6-1.79 \ldots \ldots \ldots \ldots$ & 84.4 & 40.0 & 18 & 78.5 & 182.3 & 51 \\
\hline 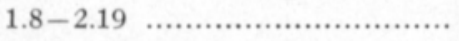 & 63.6 & 39.7 & 7 & 38.9 & 87.9 & 52 \\
\hline 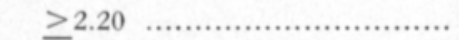 & 62.6 & 27.4 & 5 & 29.3 & 11.7 & 27 \\
\hline
\end{tabular}

According to the results it seems that the amount of free formaldehyde is at its highest in unfermented Viherliuos silages; in some it was so high that after feeding these silages there would be the possibility of the transfer of formaldehyde to milk.

\section{REFERENCES}

Aosc 1975. Association of Official Agricultural Chemists, Official Methods of Analysis. 12th Ed., Washington.

BeCK, Th. \& Gross, F. 1974. Zur Frage der Rückstande bei der Wervendung formaldehydhaltiger Zusatzmittel bei der Gärfutterbereitung. Das wirtschaftseigene Futter 19: $282-289$.

Firmin, J. L.; \& Gray, D. O. 1974. A versatile sensitive method for the detection of organic acids and organic phosphates on paper chromatograms. J. Chromatogr. 94: 294-297.

Heikonen, M., Moisio, T. \& KreUla, M. 1976. Säilörehun sokerit. Karjatalous 52 (8) 4-7.

Honig, H. \& RoHR, K. 1973. Über den Einfluss von Formalin und formalinhaltigen Zusatzmitteln auf der Silierverlauf und die Vormagenverdauung bei Milchkühen. Das wirtschaftseigene Futter 19: 21-30.

KiURU, V., Moisio, T. \& KreUlA, M. 1975. Säilörehujen käymistapahtumista sekä vaikutuksesta lehmän sonnan voihappobasillipitoisuuteen. Karjantuote 3:4-8.

Krevla, M. \& RauramaA, A. 1976. Transfer of formaldehyde from feed to milk during the feeding of fresh cut grass treated with formaldehyde-containing preservative. J. Sci. Agric. Soc. Finl. 48: 154-157.

Ms received April 14, 1977 


\section{SELOSTUS}

Formaldehydiä sisältävällä säilöntäaineella tehtyjen säilörehujen formaldehydipitoisuuksista

Aino Raurama ja Matri Kreula

Biokemiallinen Tutkimuslaitos Kalevankatu 56 b, 00180 Helsinki 18

Vapaa formaldihydipitoisuus määritettiin 180 Viherliuoksella säilötystä rehunäytteestä satokaudelta 1975. Säilörehujen formaldehydipitoisuuksien keskiarvo oli syksyllä 1975120 (vaihtelurajat $20-500$ ) ja keväällä 197659 (vaihtelurajat $10-1250$ ) $\mathrm{mg} / \mathrm{kg}$ tuoretta rehua. 